\title{
ANIMALS AND ABUSE IN 'CELESTINA': THE DOG AND THE ASS
}

\author{
Dorothy Sherman Severin \\ The University of Liverpool
}

The prevalence of animal imagery in Celestina ${ }^{1}$ has been studied by a number of critics, including Shipley and Salvador Miguel. ${ }^{2}$ I would like to explore the occurrence of two animals in the work, namely the ass and the dog. The ass is chiefly used by the characters of Celestina to abuse one another or occasionally to summon up an old saw which also has a derogatory connotation. The ass symbolizes stupidity and lust and is also a symbol of lust and metamorphosis (from its appearance in Apuleius' Golden Ass). The dog is a more ambivalent image which can represent anything from loyalty and sagacity to sudden danger, and is associated in the Middle Ages with the Devil and the hounds of hell. The dog also appears in many references cited in Celestina. ${ }^{3}$

\footnotetext{
${ }^{1}$ References are to my edition (Madrid: Alianza 1969, etc.)
}

2 See for example G. A. Shipley, "'El natural de la raposa,"' Nueva Revista de Filologia Hispánica 23 (1974), 35-64; 'Bestiary References in Femando de Rojas' La Celestina (1499): The Ironic Undermining of Authority,' La Corónica 3.2 (1975), $22-$ 23; Nicasio Salvador Miguel, "De una ave llamada rocho": para la historia literaria del ruj,' in Fernando de Rojas and 'Celestina': Approaching the Fifth Centenary. Proceedings of an International Conference in Commemoration of the 450th Anniversary of the Death of Fernando de Rojas, Purdue University 21-24 November 1991, ed. Ivy A. Corfis and Joseph T. Snow (Madison: HSMS, 1993), 393-412.

${ }^{3}$ Beryl Rowland, Animals with Human Faces: A Guide to Animal Symbolism (Knoxville: University of Tennessee Press, 1973), lists the ass's meaning as ignorance, lust, and sloth (20-28). The dog can represent loyalty and sagacity but in the Middle Ages was an image of the Devil. An attacking dog connoted evil, a pursuing one, virtue (58-66). 
The ass makes its first appearance in a metamorphosis reference in act I when Calisto speak of Melibea's golden hair tied in a fashion which, curiously, could turn men to stone (like the Medusa), and Sempronio comments in a sarcastic aside 'Más en asnos!' (54). So love turning men into asses is established as a theme. When challenged by Calisto to speak aloud Sempronio says 'Dije que estos tales no serían cerdas de asno.' and Calisto scorns the crude comparison. The next reference to the ass is in Pármeno's description of Celestina's sorcery apparatus for lovers, which includes 'sesos de asno' (62), presumably asses's brains to stupefy the love object.

Celestina makes the next two ass references, which show her contempt for both Pármeno and Calisto. Of Pármeno she remarks 'do vino el asno verná el albarda' (64), and behind Calisto's back she quotes 'Jo que te estriego, asna coja' (64). Both of these old saws indicate her low esteem for these easy dupes. Finally her panorama of a love affair, deployed to seduce Pármeno, ends 'Este es el deleite; que lo al, mejor lo hacen los asnos en el prado' (71).

In act III Celestina again compares Calisto to an ass loaded with gold in another old saw - 'no hay lugar tan alto, que un asno cargado de oro no le suba' (82). In this same act III, Celestina specifically calls Pármeno an ass when he is ashamed in Areúsa's presence - 'Llégate acá, asno' (130). In act VIII Pármeno turns the tables and compares Calisto to the lustful Apuleius who was involved in an erotic witch cult and who was turned into an ass ' $i Y$ a tal hora comieses el diacitrón, como Apuleyo el veneno, que le convertió en asno' (141). Finally it is Sosia, another dupe, who is called an ass by Elicia in act XVII after Areúsa has extracted Calisto's assignation times from the stableboy ' Oh sabia mujer! $¡ O$ Oh despidiente propio, cual le merece el asno que ha vaciado su secreto tan de ligero!' (212). In short the ass is used as an abusive comparison which is deployed to vituperate lovers who have had their brains addled by love. The ass is associated with lust and with stupidity. Love turns men into asses.

The dog presents a more complicated picture since it can symbolize everything from fidelity, to danger, to the Devil. There are also several words for dogs mentioned in Celestina. Can and perro are both used; can is more likely to have a negative connotation. We also encounter galgos and guzques.

The dog as a predator chasing the hare is mentioned in the new prologue, when the quotation that everything is a battle is explored (41). In act I the famous malapropism about 'Minerva con el can' (51) 
(Sempronio either mistakes Minerva's husband Vulcan or else he's making a joke) suggests bestiality and lust. Since it forms a pair with 'Pasife con el toro,' it is unlikely to be an scribal error. ${ }^{4}$ Pármeno's description of Celestina in the 'puta vieja' passage includes the dogs barking 'puta vieja' at her when she passes (59).

Celestina on the other hand looks for auguries in act IV and finds the lack of barking dogs on her trip to Pleberio's house a good sign (89). This notion of the dog as a dangerous and frightening animal which can be tamed is included in the long passage of bestiary lore with which Celestina tries to persuade Melibea to show pity towards Calisto:

El perro con todo su ímpetu y braveza, cuando viene a morder, si se le echan en el suelo, no hace mal; esto de piedad. (94)

In act VII Celestina exhorts Areúsa not to be the dog-in-the-manger: 'No seas el perro del hortelano' (127). Again the dog has negative, two-faced qualities.

Baiting imagery, which is so important in Celestina, appears twice in references to baited bread (pan con zarazas) used to kill dogs, once in act XI when Sempronio compares Melibea to baited bread, Calisto presumably the dog who will be killed (166), and again in act XIX when Tristán tells Sosia that Areúsa has been giving him (Sosia) baited bread to extract information from him. Here Sosia is the dog (219).

When in act XII Sempronio and Pármeno try to convince Celestina of their courage at the garden and their ruined armour which needs replacement with the proceeds of the gold chain, Celestina uses two old saws with dog imagery: 'No entremetas burlas a nuestra demanda, que con este galgo no tomarás, si yo puedo, mas liebres ... A perro viejo no cuz cuz' (182). The greyhound and hare of the prologue reappear in the Tragicomedia interpolation, whereas the original Comedia reference is to the wise old dog (Celestina) who can't be fooled by their tricks. Finally Celestina loses all patience and calls the men cowardly curs - 'los guzques ladradores a los pobres peregrinos aquejan con mayor impetu' (183). This is Celestina's last miscalculation. Again it is the threatening aspect of the dog which is emphasized. Continuing this

4 Billy Bussell Thompson, 'Misogyny and Misprint in LC. Act I,' Celestinesca 1.2 (Fall 1977), 21-28, sees the error as a humorous one showing Sempronio's ignorance and superficial cultural knowledge. 
dangerous vein, in act XIV Melibea fears for Calisto's safety from the street curs: ' $\mathrm{O} \mathrm{O}$ si por acaso los ladradores perros con sus crueles dientes, que ninguna diferencia saben hacer ni acatamiento de personas, le hayan mordido?' (189).

Areúsa in act XVII uses the dog in a subtle jibe against Sosia 'quien bien quiere a Beltrán a todas sus cosas ama' (211). The old saw should be 'quien bien quiere a Beltrán quiere a su can.' When in act XVIII Centurio tries to escape from the duty of punishing Calisto, Areúsa is not deceived - 'A otro perro con ese hueso' (215). Here the dog represents sagacity. Finally, the hounds howl at the death of Calisto, in Melibea's farewell to her father: 'Bien oyes este clamor de campanas, este alarido de gente, este aullido de canes, este grande estrépito de armas' (221). The hounds of hell bay for both her and her lover.

Both the ass and the dog are largely derogatory animal images in Celestina. The ass is used systematically as a term of abuse and has connotations of stupidity and lust. Although the dog can occasionally represent positive qualities like wisdom, it more often is also a negative and derogatory image. Dogs represent danger and treachery, and in the worst case, the diabolical hounds of hell. Rojas use of these images in both the Comedia and the Tragicomedia is systematic and intentional, leading to the devaluation of those characters associated with these animals.

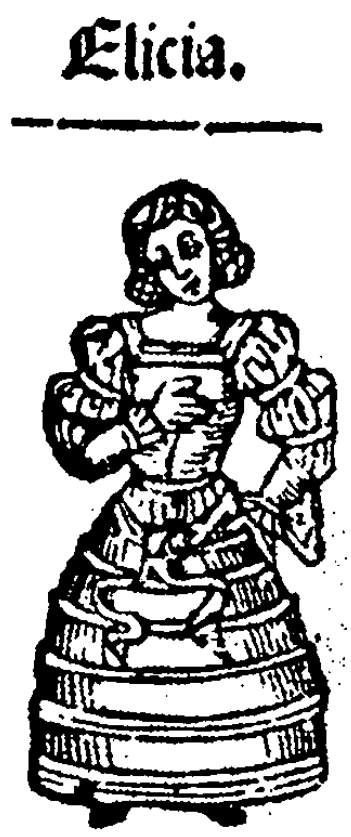

De la ed. de Salamanca 1529. 